\title{
Modificación del método de tiocianato de guanidina para extraer ADN de semen para análisis genómico en mamíferos
}

\section{Modification of a guanidinium thiocyanate to extract DNA from semen for genomic analysis in mammals}

\author{
Baldomero Alarcón-Zúñigaa, J osé Luis Zepeda-Batistaa, Agustín Ruíz-Floresa, Luis \\ J oaquín Gómez-Mezaa, J osé Guadalupe García-Muñiza, Rafael Núñez-Domíngueza, \\ Rodolfo Ramírez-Valverdea, Itzel Villegas-Velázqueza
}

\begin{abstract}
RESUMEN
Los análisis genómicos y transcriptómicos para selección y mejoramiento genético animal requieren ADN o ARN de alta concentración y pureza, proveniente de diferentes tejidos incluyendo semen. Los métodos usualmente utilizados para extraer ADN de semen son menos efectivos en cantidad y calidad de ADN, debido a los solventes y diluyente utilizados para la conservación, características físico-químicas de los espermatozoides, y fracción no celular del eyaculado. En este estudio, se proponen modificaciones al método de tiocianato de guanidina, incluyendo un segundo lavado de la muestra con solución buffer fosfato, y dos lavados con solventes orgánicos, uno fuerte (fenol:cloroformo:alcohol isoamílico) y uno débil (cloroformo:alcohol isoamílico), para retirar la proteína y diluyente presentes en la muestra. Además, se propone una incubación por separado con ARNasa para reducir contaminación de ácidos nucleicos en la medición y elaboración de diluciones para amplificación por PCR. La precipitación agregó al isopropanol de la metodología original $3 \mathrm{M}$ de acetato de sodio para retirar restos de posibles inhibidores de la PCR. Finalmente, se incluyeron centrifugaciones de alta velocidad y decantaciones para evitar la necesidad de separación mecánica del ADN y la proteína. EI ADN extraído con el método propuesto no presentó degradación, y la calidad y cantidad fueron mejores $(P<0.0001)$, encontrándose una media de $1.84 \pm 0.09$ en el rango $260 / 280$ y $156.99 \pm 7.29 \mathrm{ng} / \mu \mathrm{l}$ para la variable de concentración. El presente método de extracción es una alternativa de bajo costo, viable para obtener ADN de semen con características necesarias para análisis genómicos en mamíferos.
\end{abstract}

PALABRAS CLAVE: ADN genómico, Extracción de ADN, Semen, Mamíferos.

\begin{abstract}
The genomic and transcriptomic analyses for selection and genetic improvement require DNA or RNA of high concentration and purity, coming from different tissues, including semen. The DNA may be from hair, saliva, cartilage, blood, or semen. The methods usually used to extract DNA from semen have low efficiency in terms of quantity and quality. This is due to the solvents and dilutors used for semen conservation, physical and chemical characteristics of sperms, and non-cellular fraction of ejaculate. In this study, modifications to the guanidinium thiocyanate method are proposed, including a second washing of the sample using a phosphate buffer solution, and two washing with organic solvents, one strong (phenol:chloroform:I soamyl alcohol), and one weak (chloroform:isoamyl alcohol), to get rid of the protein and dilutors present in the sample. Additionally, it is proposed a separate incubation with RNA-ase to reduce contamination of nucleic acids during measurement and dilution preparation for PCR amplification. The precipitation added to the isopropanol of the original method $3 \mathrm{M}$ sodium acetate to separate the residuals of potential PCR inhibitors. Finally, there were included high-speed centrifugation and decantation to avoid the need for mechanical separation of the DNA and protein. The DNA extracted with the modified method did not present degradation, and the quality and quantity were better $(P<0.0001)$ than the original, with a mean of $1.84 \pm 0.09$ in the range of 260 / 280 and $156.99 \pm 7.29 \mathrm{ng} / \mu \mathrm{l}$ for concentration. The present method of extraction is a viable low-cost alternative to obtain DNA from semen with the necessary characteristics for genomic analysis in mammals.
\end{abstract}

KEY WORDS: Genomic DNA, DNA extraction, Semen, Mammals.

Recibido el 11 de junio de 2015. Aceptado el 23 de noviembre de 2015.

A Posgrado en Producción Animal, Departamento de Zootecnia, Universidad Autónoma Chapingo, Carretera México-Texcoco km 38.5. CP 56230, Chapingo, Estado de México. México. arf@correo.chapingo.mx. Correspondencia al tercer autor. 


\section{INTRODUCCIÓN}

El análisis genómico de animales domésticos se usa ampliamente para la identificación, determinación o comparación de evaluaciones genómicas intra-poblacionales, tales como la secuenciación de ADN, variación estructural, genotipado, expresión génica, o anotación de elementos regulatorios o funcionales. Los métodos para el análisis genómico típicamente demandan grandes concentraciones de ADN de alta pureza y sin contaminantes de acuerdo a la fuente donde se obtiene la muestra (tejido piloso, saliva, sangre, cartílago o semen), que pudieran influir en las metodologías para cada estudio(1).

La extracción de ADN de semen, a diferencia del uso de células somáticas, considera ciertas dificultades en la metodología de purificación, como las características físicas y sobre todo químicas de la compactación nuclear en espermatozoides, la composición de la fracción no celular del eyaculado y los diluyentes utilizados en la conservación de semen congelado $(1,2,3)$. Los espermatozoides contienen proteínas nucleares especializadas de bajo peso molecular denominadas protaminas, que crean una cromatina al menos seis veces más densa que las histonas de células somáticas, y que mantienen el ADN muy condensado en el acrosoma; además, la membrana plasmática se encuentra unida por enlaces disulfuro, haciéndola resistente a la desnaturalización mediante agentes químicos utilizados en los métodos tradicionales de extracción de ADN de células somáticas $(4,5)$. El acrosoma de los espermatozoides contiene hialuronidasa, enzima que ataca el ácido hialurónico al hacer contacto con el óvulo, pero en la extracción de ADN, esta enzima se libera al romperse la membrana plasmática pudiendo degradar el ADN. De manera similar, las mitocondrias del conector del espermatozoide, al ser lisado, son liberadas manteniendo su actividad oxidativa, pudiendo dañar el ADN presente en el medio $(6,7)$.

Por otra parte, la fracción no celular del eyaculado contiene diversos minerales como zinc

\section{INTRODUCTION}

Genetic analysis is widely used in domestic animals for the identification and comparison of genetic variations within a population. It is a vital component of techniques such as DNA sequencing, structural variation, genotyping, gene expression and identifying regulatory or functional elements. Techniques for genetic analysis typically require large amounts of highly pure DNA. Genetic source material (e.g. follicle tissue, saliva, blood, cartilage, semen) determines the methods most appropriate for genetic analysis(1).

Unlike DNA extraction from somatic cells, with semen there are a number of difficulties in the purification methodology; these involve the physical and chemical characteristics of spermatozoid nuclear compaction, composition of the ejaculate's non-cellular fraction, and the diluents used in the preservation of frozen sperm $(1,2,3)$. Spermatozoids contain specialized, low-molecular weight nuclear proteins called protamines. These generate a chromatin that is at least six times denser than the histones of somatic cells and that maintain the DNA cells condensed in the acrosome. In addition, their plasmatic membrane is linked by disulfide bonds, making it resistant to the chemical agents used in traditional somatic cell DNA extraction methods $(4,5)$. The spermatozoids' acrosome contains hyaluronidase, an enzyme that attacks hyaluronic acid when it contacts the ovule. In DNA extraction, however, hyaluronidase is released when the plasmatic membrane ruptures, possibly degrading the DNA. Another possible way DNA can be damaged is when spermatozoid connector mitochondria are lysed and released because they preserve their oxidative activity and can damage any DNA in the medium(6,7).

The non-cellular fraction of the ejaculate contains a number of minerals, such as zinc and copper, which originate in the prostate. If these are not removed from the final DNA sample, they interfere in the polymerase chain reaction (PCR). Moreover, glycogen and some 
y cobre, provenientes de la próstata, que si no se retiran de la muestra de $A D N$ final, interfieren en la reacción en cadena de polimerasa (PCR), además del glucógeno y algunos lípidos presentes que sirven como fuente de energía $(6,7)$. Además, en el semen congelado, los diluyentes usados simulan la composición de la fracción no celular del eyaculado, por lo que al poseer en mayor medida proteínas, lípidos y minerales como $\mathrm{Cr}, \mathrm{Fe}, \mathrm{Zn}, \mathrm{Cu}, \mathrm{Cl}, \mathrm{K}, \mathrm{P}, \mathrm{Ca}$, $\mathrm{Mg}, \mathrm{Na}$, y S, es necesario retirarlos por completo de las muestras, previo a la extracción de los ácidos nucleicos, para evitar interferencia durante la $\operatorname{PCR}(7,8,9)$.

La metodología propuesta en la presente técnica se estableció a partir del método de tiocianato de guanidina(10) y otras técnicas para obtener ADN de muestras de semen congelado, con la calidad y cantidad requeridas por las nuevas técnicas de identificación genómica. Adicionalmente, se elimina por completo la necesidad de separar mecánicamente la proteína restante en dichas técnicas, ya que de no retirarse puede ser un factor de variabilidad en la lectura de las muestras $(7,10,11)$. El objetivo de este estudio fue modificar y evaluar una técnica que pueda desempeñarse de manera eficiente, a partir del método del tiocianato de guanidina, para obtener ADN genómico de alto peso molecular, con el fin de usarse en técnicas de identificación genómica en animales que requieren alta pureza en el rango de longitud de onda en $260 / 280$ de 1.8 a 2.0 , y de $260 /$ 230 de 2.0 a 2.2 .

\section{MATERIAL Y MÉTODOS}

El estudio se desarrolló en el Laboratorio de Genética Molecular del Departamento de Zootecnia de la Universidad Autónoma Chapingo.

\section{Material biológico}

Las muestras utilizadas para las pruebas de extracción de ADN se obtuvieron de pajillas de semen congelado comercial $(0.25 \mathrm{ml})$ y caseras lipids in the ejaculate can function as energy sources $(6,7)$. Finally, when semen is frozen, the diluents added to preserve it simulate the composition of the non-cellular fraction. They contain proteins, lipids and minerals (e.g. Cr, $\mathrm{Fe}, \mathrm{Zn}, \mathrm{Cu}, \mathrm{Cl}, \mathrm{K}, \mathrm{P}, \mathrm{Ca}, \mathrm{Mg}, \mathrm{Na}$, and S), making it necessary to remove them completely from samples before DNA extraction to prevent any interference with the $\operatorname{PCR}(7,8,9)$.

The present proposed technique is based on the guanidinium thiocyanate method, and other techniques for extracting DNA from frozen semen, which result in DNA samples of the necessary quality and quantity for current genetic identification techniques. It completely eliminates the need to mechanically separate the remaining protein; a required step in existing techniques because this protein can lead to widely varying readings between samples if not removed $(7,10,11)$. The present study objective was to develop and evaluate a technique based on the guanidinium thiocyanate method that can efficiently extract high-molecular weight genomic DNA from frozen bull semen for use in genetic identification techniques that require high purity and operate within values of 1.8 to 2.0 in the 260/280 wavelength range, and 2.0 to 2.2 in the $260 / 230$ range.

\section{MATERIAL AND METHODS}

All analyses were performed in the Laboratorio de Genética Molecular of the Departamento de Zootecnia, Universidad Autónoma Chapingo.

Biological material

DNA extraction was done using $0.25 \mathrm{ml}$ straws of commercial frozen bovine semen, and $0.5 \mathrm{ml}$ straws of frozen semen prepared in the laboratory. The lab-prepared straws were tested with a commercial diluent (Triladyl ${ }^{\circledR}$; contains TRIS, citric acid, sugar, buffers, glycerin, ultrapure water, antibiotics and egg yolk). Extraction tests were done using frozen semen straws from five bulls ( 1 Holstein, 4 J ersey). 
(0.5 ml) elaboradas en el laboratorio. Las pajillas preparadas en laboratorio se probaron con diluyentes comerciales (Triladyl, que contiene TRIS, ácido cítrico, azúcar, tampones, glicerina, agua ultrapura, y antibióticos) y yema de huevo. Las pruebas de extracción se realizaron con pajillas de semen congelado de cinco toros, uno Holstein y cuatro Jersey.

\section{Extracción de ADN}

La metodología de extracción de ADN se basó en los métodos: a) fenol-cloroformo $(12)$, b) tiocianato de guanidina, y c) el propuesto en este estudio, el cual se realizó con cada tipo de muestras de semen congelado, las cuales se lavaron con $1 \mathrm{ml}$ de solución buffer salino fosfato, seguido de una centrifugación a 800 rpm por $10 \mathrm{~min}$ a temperatura ambiente, repetido en dos ocasiones. El pellet recuperado se incubó con $1 \mathrm{ml}$ de solución de lisis $(6 \mathrm{M}$ tiocianato de guanidina, $30 \mathrm{mM}$ citrato de sodio ( $\mathrm{pH}$ 7.0), $0.5 \%$ sarkosyl, $0.20 \mathrm{mg} / \mathrm{ml}$ proteinasa $\mathrm{K}$ y $0.3 \mathrm{M} \beta$-mercaptoetanol) por $4 \mathrm{~h}$ a $55{ }^{\circ} \mathrm{C}$ en baño maría. Al término de la incubación se recuperó el sobrenadante y se lavó con $1 \mathrm{ml}$ de solución $\mathrm{FCl}$ (25, fenol: 24, cloroformo: 1, alcohol isoamílico), y después se centrifugó a $9,000 \mathrm{rpm}$ por $10 \mathrm{~min}$ a $4{ }^{\circ} \mathrm{C}$. El procedimiento se repitió con la solución de $\mathrm{Cl}$ (24, cloroformo: 1, alcohol isoamílico), y el sobrenadante se incubó con ARNasa a $37{ }^{\circ} \mathrm{C}$, por $30 \mathrm{~min}$. Posteriormente se precipitó con isopropanol frío y 0.1 volúmenes de $3 \mathrm{M}$ acetato de sodio, y se incubó toda la noche a $-20^{\circ} \mathrm{C}$. Se centrifugó a 9,000 rpm por $10 \mathrm{~min}$ a $4{ }^{\circ} \mathrm{C}$, decantando el sobrenadante y se lavó el pellet con etanol $70 \%$ frío. Finalmente, se centrifugó y se decantó nuevamente, dejándose secar y se re-suspendió nuevamente en $50 \mu$ de buffer TE.

\section{Análisis de ADN}

La concentración y calidad del ADN en cada uno de los tres métodos evaluados se determinó con: 1) nano-espectrofotómetro (ND-1000 Nandrop ${ }^{\circledR)}$ para determinar la concentración de ADN, relación de longitudes de onda 260/

\section{DNA extraction}

Extraction was done using three methods: a) phenol-chloroform(12); b) guanidinium thiocyanate; and c) the combination method proposed in the present study. Each technique was run using both the commercial and labprepared straws, which were prepared in the same manner. After thawing, the semen was washed with $1 \mathrm{ml}$ saline phosphate buffer solution, centrifuged at $800 \mathrm{rpm}$ for $10 \mathrm{~min}$ at room temperature, and then washed again in the same way. The resulting pellet was incubated with $1 \mathrm{ml}$ lysis solution (6 M guanidinium thiocyanate, $30 \mathrm{mM}$ sodium citrate [pH 7.0], $0.5 \%$ sarkosyl, $0.20 \mathrm{mg} / \mathrm{ml}$ proteinase $\mathrm{K}$ and $0.3 \mathrm{M} \beta$-mercaptoethanol) for $4 \mathrm{~h}$ at $55^{\circ} \mathrm{C}$ in a water bath. When incubation was complete, the supernatant was recovered, washed with 1 $\mathrm{ml} \mathrm{FCl}$ solution (25, phenol: 24, chloroform: 1, isoamyl alcohol), and centrifuged at 9,000 rpm for $10 \mathrm{~min}$ at $4{ }^{\circ} \mathrm{C}$. This procedure was repeated with the $\mathrm{Cl}$ solution (24, chloroform: 1 , isoamyl alcohol) and the supernatant incubated with RNAse for $30 \mathrm{~min}$ at $37{ }^{\circ} \mathrm{C}$. It was then precipitated with cold isopropanol and 0.1 volumes of $3 \mathrm{M}$ sodium acetate, and incubated overnight at $-20^{\circ} \mathrm{C}$. It was then centrifuged at $9,000 \mathrm{rpm}$ for $10 \mathrm{~min}$ at $4{ }^{\circ} \mathrm{C}$, the supernatant decanted and the pellet washed with cold $70 \%$ ethanol. Finally, it was centrifuged, the supernatant decanted, the remaining contents allowed to dry, and these resuspended in $50 \mu \mathrm{l}$ TE buffer.

\section{DNA analysis}

For all three methods, DNA concentration was evaluated with a nano-spectrophotometer (ND1000 Nanodrop ${ }^{\circledR}$ ), using the $260 / 230$ and 260 / 280 wavelength ranges. Quality was determined by electrophoresis in 1\% gel to measure sample contamination and degradation.

\section{Statistical analysis}

For all 65 samples, DNA concentration and quality in each method were initially analyzed using the effects of breed and individual, and 
MODIFICACIÓN DEL MÉTODO PARA EXTRAER ADN DE SEMEN

Cuadro 1. Medias de mínimos cuadrados ( \pm error estándar) para calidad y cantidad de ADN obtenidas con tres métodos de extracción de ADN de semen

Table 1. Least means squares ( \pm standard error) results for quality and quantity of DNA extracted from frozen bull semen using three methods

\begin{tabular}{lccr}
\hline Methods & $260 / 280$ & $260 / 230$ & {$[\S]$} \\
\hline Phenol-chloroform $^{\dagger}$ & $1.47 \pm 0.11^{\mathrm{c}}$ & $-0.41 \pm 0.41^{\mathrm{b}}$ & $45.69 \pm 8.60^{\mathrm{b}}$ \\
Guanidinium thiocyanate $^{\text {I }}$ & $2.19 \pm 0.10^{\mathrm{a}}$ & $0.80 \pm 0.37 \mathrm{a}$ & $151.57 \pm 7.77^{\mathrm{a}}$ \\
Modified guanidinium $^{\S}$ & $1.84 \pm 0.09 \mathrm{~b}$ & $0.66 \pm 0.35 \mathrm{~b}$ & $156.99 \pm 7.29 \mathrm{a}$ \\
\hline
\end{tabular}

† Birren et al, 1997; I Hossain et al, 1997; § Developed in present study.

abc Least squares means with different letters in the same column are different $(P<0.05)$.

230 y $260 / 280$, y 2 ) con electroforesis en gel de agarosa al $1 \%$ para determinar el grado de contaminación y degradación de las muestras.

Análisis estadístico

La concentración y calidad del ADN ( $\mathrm{n}$ total= 65) obtenidos con cada uno de los tres métodos evaluados se analizaron con un modelo que inicialmente incluyó los efectos fijos de raza, individuo y la covariable volumen de semen de la pajilla. Dado que ninguno de estos efectos fueron significativos en los análisis preliminares, para el análisis final se eliminaron del modelo, el cual sólo consideró el efecto fijo de método de extracción ( $1=$ fenol cloroformo, $2=$ tiocianato de guanidina, y $3=$ tiocianato de guanidina modificado). Los análisis se realizaron con el procedimiento GLM del programa estadístico SAS(13).

\section{RESULTADOS Y DISCUSIÓN}

Las medias de mínimos cuadrados obtenidas en este estudio (Cuadro 1) indican diferencias entre los métodos $(\mathrm{P}<0.0001)$ para el rango de $260 / 280$ y la concentración de la muestra, lo que confirma una calidad y cantidad superiores de ADN extraído con el método modificado respecto de las muestras realizadas con los métodos de Hossain et al(10) y Birren et al(12). Por su parte, la ausencia de diferencia estadística $(P=0.0705)$ en el rango $260 / 230$ evidencia la limpieza total de ARN de las muestras en los the covariable of semen straw volume. None had a significant effect and were therefore eliminated from the model. The final analysis considered only the effect of extraction method ( $1=$ phenol-chloroform; $2=$ guanidinium thiocyanate; $3=$ modified guanidinium thiocyanate). All analyses were run with the GLM procedure in the SAS statistical package(13).

\section{RESULTS AND DISCUSSION}

The least means squares analysis identified differences $(P<0.0001)$ between methods in the $260 / 280$ wavelength range and between sample concentrations (Table 1 ). This confirms that the modified method extracted a higher quality and quantity of DNA compared to the methods of Hossain et al(10) and Birren et al(12). Absence of difference in the 260/230 range indicates total cleansing of RNA from the samples was attained in all three extraction methods. These results are supported by the electrophoresis analysis results of the DNA samples extracted with each evaluated method (Figure 1).

When extracted with the phenol-chloroform method, DNA samples exhibited low quality $(1.47 \pm 0.11$ at 260/280; and $-0.41 \pm 0.41$ at 260/230), and low concentrations. Electrophoresis demonstrated an absence of DNA, possibly due to degradation and loss from total washing during the protocol. This coincides with previous studies $(1,10)$ in which DNA 
tres métodos de extracción de ADN. Dichos resultados son respaldados por los análisis con electroforesis de las muestras de ADN extraídas con los tres métodos (Figura 1 ).

Las muestras obtenidas con el método de fenol cloroformo mostraron una mala calidad al analizarlas con el nano-espectrofotómetro, presentando valores de $1.47 \pm 0.11$ y $-0.41 \pm$ 0.41 en los rangos $260 / 280$ y 260/230, así como una menor concentración. La electroforesis mostró ausencia de ADN, debido posiblemente a una degradación y pérdida por lavado total durante el desarrollo del protocolo. Al respecto, Hossain et al(10) y Manuja et al(1) observaron alta o total degradación del ADN en las muestras obtenidas con el método de fenol cloroformo(12), aun cuando las calidades obtenidas por espectrofotometría fueron mayores a 1.8 para el rango 260/280, siendo una posible razón de esto la presencia de ARN y restos de proteínas de bajo peso molecular en las muestras analizadas por ambos autores. degradation was extensive or complete when using the phenol-chloroform method(12). However, in these same studies DNA quality surpassed 1.8 at $260 / 280$, possibly due to the presence of RNA and the remains of lowmolecular weight proteins.

The guanidinium-thiocyanate method produced good quality DNA samples with higher concentrations than in the phenol-chloroform method. Nonetheless, electrophoresis showed slight DNA degradation in the samples and considerable presence of protein in the gels' upper fraction (Figure 1, rows 5 to 8). Slight DNA degradation and the presence of protein were also observed in samples in a previous study $(10)$, partially due to the need for DNA separation by protein traction, causing incomplete purification of the nucleic acids.

The modified guanidinium-thiocyanate method proposed here produced high quality and quantity DNA samples. Nano-spectrophotometry

Figura 1. Electroforesis en gel de agarosa al 1\% de muestras de semen de bovino preparados con tres métodos de extracción de ADN

Figure 1. $1 \%$ gel electrophoresis of bovine semen prepared with one of three DNA extraction methods

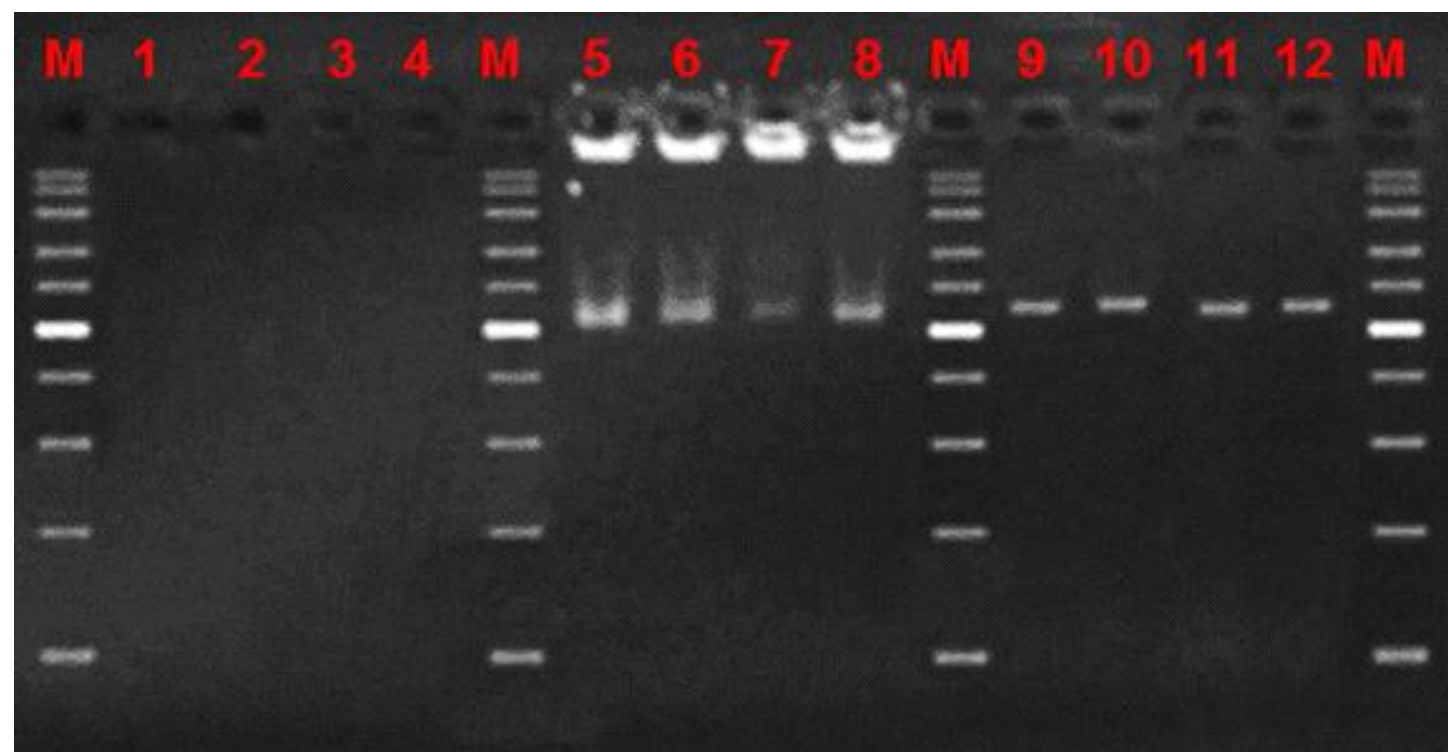

Phenol-chloroform (lanes 1 to 4); guanidinium thiocyanate (lanes 5 to 8); and modified guanidinium thiocyanate (lanes 9 to 12). "M" lanes are $1 \mathrm{~kb}$ molecular weight markers. 
Por otra parte, las muestras extraídas con el método de tiocianato de guanidina tuvieron mejor calidad y mayor concentración que las muestras extraídas con el método de fenol cloroformo. Sin embargo, los resultados de electroforesis mostraron una ligera degradación del ADN de las muestras y una considerable presencia de proteína en la fracción superior del gel (Figura 1, carriles 5 a 8). Hossain et al(10) también observaron de ligera a nula degradación del ADN con presencia de proteína en las muestras obtenidas, debido en parte al requerimiento de separación del ADN por tracción de la proteína presente en la muestra, propiciando de esta forma una purificación incompleta de los ácidos nucleicos.

Por último, el método propuesto en este estudio produjo muestras con calidad y cantidad altamente deseables y confiables. Tanto en los resultados del nano-espectrofotómetro como en la electroforesis, la calidad en los rangos 260/ 230 y 260/280 fueron entre 1.8 y 2.2 (Cuadro 1 ), y poca o nula degradación del ADN aparente en la electroforesis, con ausencia de proteínas y otros factores contaminantes en las muestras, considerando que las muestras tuvieron óptimas condiciones para usarse en análisis genómicos (Figura 1, carriles 9 a 12).

La extracción de ADN con los métodos propuestos por Birren et al(12) y Hossain et al(10) se realizó para comparar la eficiencia de extracción de ADN de muestras de semen congelado de bovino con la metodología propuesta en este estudio. El método propuesto, adicionó un segundo lavado a las muestras con solución buffer fosfato, ya que aunque el volumen del eyaculado de la mayoría de las especies de interés zootécnico es mayor que el del humano, y la densidad es de 0.2 a 30 veces mayor(6), el segundo lavado permitió incrementar la pureza del ADN extraído. Además, los eyaculados de toro, cerdo y caballo, presentan una concentración de 1.7 a 3.4 veces mayor de $\mathrm{Cl}, \mathrm{K}$, y Ca, que la del humano, y de no retirarse de las muestras de semen estos iones pueden generar resultados erróneos showed quality to be between 1.8 and 2.2 in both wavelength ranges (i.e. 260/230 and 260/ 280) (Table 1). Little or no DNA degradation was apparent in the electrophoresis analysis, with a total absence of proteins and other contaminating factors (Figure 1, rows 9 to 12). The samples provided optimum conditions for use in genetic analysis.

Extraction efficiency from frozen bovine semen samples using the modified method proposed here was compared to the efficiency reported in previous studies $(10,12)$. In the proposed method, a second washing with phosphate buffer solution was added to the previous methods to increase DNA purity. This was done even though livestock species normally produce more ejaculate than humans and its density is 0.2 to 30.0 times greater(6). In addition, bull, pig and horse ejaculates have $\mathrm{Cl}, \mathrm{K}$ and $\mathrm{Ca}$ concentrations 1.7 to 3.4 times higher than human ejaculate. If these ions are not removed from semen samples they can cause erroneous results during genetic analyses and even inhibit PCR amplification of $\operatorname{DNA}(7,9)$.

In the proposed method, two washings with organic solvents followed by high velocity centrifuging were used even though use of organic solvents is reported to make isolation of non-degraded DNA more difficult(14). However, this modification helped to completely remove the protein that had not degraded in previous steps. It also aided in preserving DNA integrity by consolidating it into a pellet, thus preventing chemical damage by completely separating it from the organic solvent, any compounds in the ejaculate, and any diluents added for semen preservation. Addition of the phenol:chloroform: isoamyl alcohol washing step removed high-molecular weight proteins and residual chelating agents in the samples while the subsequent chloroform: isoamyl alcohol washing removed low-molecular weight proteins and any chelant traces remaining after the first washing $(7,9)$.

Since Hossain et al(10) reported that RNA material was preserved in some samples, an 
durante los análisis genómicos, pudiendo inclusive inhibir la amplificación de $\operatorname{ADN}$ por $\operatorname{PCR}(7,9)$.

En la metodología planteada se llevaron a cabo dos lavados con solventes orgánicos, seguidos de centrifugaciones de alta velocidad, aun cuando Sambrook et al(14) documentaron la dificultad de aislamiento de ADN no degradado por métodos que involucren solventes orgánicos. Además de retirar por completo la proteína presente en las muestras no degradada en pasos previos, este método permitió conservar la integridad del ADN al consolidarlo en un pellet que evita el daño químico al separarlo por completo del solvente orgánico y demás compuestos propios del eyaculado o el diluyente utilizado para conservar el semen. La inclusión del lavado fuerte (fenol:cloroformo:alcohol isoamílico) en el método, retiró las proteínas de alto peso molecular y agentes quelantes residuales presentes en las muestras; en el mismo sentido, el posterior lavado débil (cloroformo:alcohol isoamílico) retiró las proteínas de bajo peso molecular y agentes quelantes restantes después del primer lavado $(7,9)$.

Debido a que algunas muestras analizadas con el método propuesto por Hossain et al(10) conservaron material de ARN, se agregó una incubación con ARNasa, asegurando de esta manera la obtención de ADN genómico puro, evitando valores imprecisos al medir las concentraciones por medio del nanoespectrofotómetro, que puedan conducir a un cálculo erróneo al momento de elaborar diluciones de las muestras de ADN para la amplificación de ADN mediante PCR(7).

Finalmente, el $3 \mathrm{M}$ acetato de sodio incluido en la incubación del ADN con isoprapanol a $-20^{\circ}$ $C$, hizo más eficiente la precipitación del ADN de la muestra, ya que aumentó el poder iónico de la solución retirando los restos de solventes orgánicos y de medicamentos provenientes del diluyente, en el caso de las muestras de semen congelado(8). Las posteriores centrifugaciones, decantaciones y lavado con etanol $70 \%$ retiraron por completo los remanentes del acetato de
RNAase incubation was added in the modified method. This ensured the DNA in the samples was genetically pure, thus avoiding imprecise values when measuring concentrations by nanospectrophotometry. If values are not exact, DNA sample dilution calculations can contain errors which affect PCR amplification results(7).

Finally, use of $3 \mathrm{M}$ sodium acetate in DNA incubation with isopropanol at $-20{ }^{\circ} \mathrm{C}$ made DNA precipitation more efficient by augmenting solution ionic strength and removing organic solvents and diluent medications (8). Centrifuging, decanting and washing with $70 \%$ ethanol removed all sodium acetate and sarkosyl remnants.

\section{CONCLUSIONS AND IMPLICATIONS}

The modified DNA extraction method proposed here for use with frozen bovine semen produced highly pure DNA samples free of degradation and with extremely low or null protein content. It is also simple and low-cost, and the resulting sample DNA quality and quantity are appropriate for genetic analyses, such as SNPs and microsatellites, that are commonly used in mammals.

\section{ACKNOWLEDGEMENTS}

The research reported here was financed by the Consejo Nacional de Recursos Genéticos Pecuarios (CONARGEN) (2013-001), Asociación Mexicana de Criadores de Ganado Jersey de Registro and the Universidad Autónoma Chapingo, México (DGIP-11550301). The Consejo Nacional de Ciencia y Technologia (CONACYT) provided a Masters in Science scholarship for the second author.

End of english version

sodio y del sarkosyl proveniente de la solución de lisis. 


\section{CONCLUSIONES E IMPLICACIONES}

El método modificado de extracción de ADN a partir de semen congelado descrito en este estudio permite obtener muestras de ADN libres de degradación, de mayor pureza y menor o nula presencia de proteínas. Además, es sencillo, barato, y la calidad y cantidad de las muestras es apropiada para la realización de análisis genómicos de ADN, como SNPs y microsatélites en mamíferos.

\section{AGRADECIMIENTOS}

Este proyecto fue apoyado por el Consejo Nacional de Recursos Genéticos Pecuarios (CONARGEN) (2013-001), Asociación Mexicana de Criadores de Ganado Jersey de Registro y Universidad Autónoma Chapingo, México (DGIP11550301). Al CONACYT por el financiamiento de los estudios de Maestría en Ciencias del segundo autor.

\section{LITERATURA CITADA}

1. Manuja A, Manchanda S, Kumar B, Khanna S, Sethi RK. Evaluation of different methods of DNA extraction from semen of buffalo (Bubalus bubalis) bulls. Buffalo Bull 2010; 29(2): 109-128.
2. Weyrich A. Preparation of genomic DNA from mammalian sperm. Current Protoc Mol Biol 2012;2(2.13):1-3.

3. Griffin J. Methods of sperm DNA extraction for genetic and epigenetic studies. Spermatogenesis. Methods Protoc 2013; 927:379-384.

4. Van Kooij RJ, Van Oost BA. Determination of sex ratio of spermatozoa with a deoxyribonucleic acid-probe and quinacrine staining: a comparison. Fertil Steril 1992;58:384386.

5. Evenson D, Jost L. Sperm chromatin structure assay: DNA denaturability. Methods Cell Biol 1994;42:159-176.

6. Mann T. The biochemistry of semen. New York, USA: John Wiley and Sons, Inc; 1954.

7. Opel KL, Chung D, McCord B. A study of PCR inhibition mechanisms using real time. J Foren Sci 2009;55:25-33.

8. Herold FC, de Haas K, Cooper D, Colenbrander B, Nöthling JO, Theunisen W, et al. Comparison of three different media for freezing of epididymal sperm from the African buffalo (Syncerus caffer) and influence of equilibration time on the post-thaw sperm quality. Onderstepoort J Vet Res 2004; 71:203-210.

9. Rådström $P$, Knutsson R, Wolffs $P$, Lövenklev $M$, Löfström C. Pre-PCR processing. Strategies to generate PCR-compatible samples. Mol Biotechnol 2004; 26:133-146.

10. Hossain AM, Rizk B, Behzadian A, Thorneycroft J H. Modified guanidinium thiocyanate method for human sperm DNA isolation. Mol Hum Reprod 1997;3(11):953-956.

11. Bahnak BR, Wu QY, Coulombel L, Drouet L, Kerbiriou-Nabias $D$, Meyer D. A simple and efficient method for isolating high molecular weight DNA from mammalian sperm. Nucleic Acids Res 1988; 16: 1208-1209.

12. Birren B, Green ED, Klapholz S, Myers RM, Roskans J. Standard methods used for isolating DNA. In: Genome analysis: A laboratory manual. New York, USA: Cold Spring Harbor Laboratory Press; 1997:617-629.

13. SAS. SAS/STAT User's Guide (Release 9.3). SAS Inst. Inc. Cary, N.C. 2014.

14. Sambrook J, Fritsch EF, Maniatis T. Molecular cloning: A laboratory manual. 2nd ed. New York, USA: Cold Spring Harbor Laboratory Press; 1990. 
